\title{
Clear Cell Papillary Renal Cell Carcinoma: A Novel Category of Renal Cell Neoplasm
}

\section{Borislav A Alexiev*}

Department of Pathology, University of Maryland School of Medicine, Baltimore, USA

Clear cell Renal Cell Carcinoma (clear cell RCC) and papillary Renal Cell Carcinoma (papillary RCC) are the most common carcinomas of the renal tubular epithelium and distinguishing them from one another is important because they have different prognoses [1-3]. Although most of the time they can be distinguished easily in routine sections, occasionally, overlapping morphologic findings make classification difficult. Rarely, RCC are encountered in which there are areas of papillary architecture, but there are extensive populations of cells with clear cytoplasm [1-3]. In this situation, it is unclear whether they should be classified as clear cell RCC or papillary RCC. Recently, a distinctive tumor characterized by papillary architecture and composed entirely of clear cells has been described as arising in kidneys with or without end-stage renal disease and is designated as "Clear Cell Papillary Renal Cell Carcinoma" (CCPC) [1-3].

The tumor architecture is predominantly papillary, with rare areas showing a solid-acinar, tubular, microcystic, or macrocystic features [1-4]. Even in the predominantly cystic areas, the lining cells frequently show papillary infoldings. Irrespective of the architecture, the tumors are almost entirely composed of cells with clear cytoplasm (Figure 1A and 1B). Nuclei are mostly low grade (Fuhrman's grade 1 or 2). A prominent feature is the polarization of the nuclei in a linear array away from the basal aspects of the cells [1-4]. The subnuclear and supranuclear clarity of the cytoplasm creates a superficial resemblance to the glands of early secretory endometrium [1-3]. Mitotic figures are absent. No foamy macrophages or calcifications are observed in the cores of the papillae or in the lumens of the cysts.

The differential diagnosis may be difficult considering that papillary RCC may exhibit components of cells with clear cytoplasm, and clear

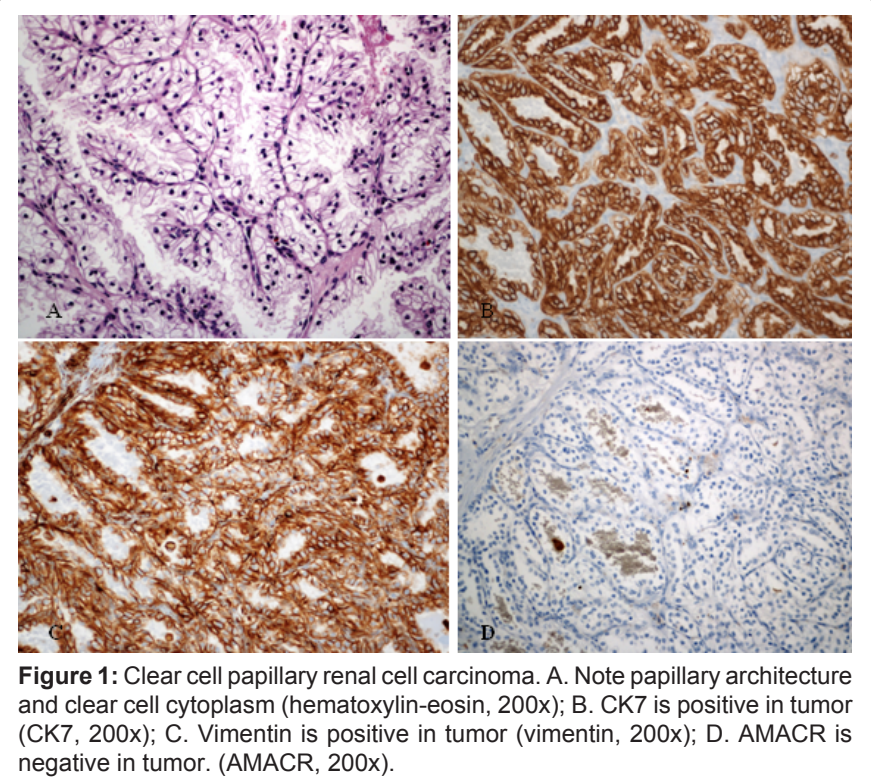

cell renal RCC can show a pseudopapillary architecture. Although CCPC may be difficult to distinguish from papillary RCC with clear cell changes on the basis of morphologic findings alone, these two entities have different immunohistochemical and cytogenetical profiles [1-3]. AMACR immunoreactivity and gains of chromosomes 7 and 17 are not observed in CCPC, whereas papillary RCC typically express AMACR and show gains of chromosomes 7 and 17. On the other hand CCPC show a strong immunoexpression for $\mathrm{CK} 7$ and lack the deletion of 3p, whereas clear cell RCC are negative for CK7 and frequently show $3 p$ deletion (Figure 1C and 1D) [1-4]. All CCPC typically express vimentin (at least focally) and are RCC negative [4].

Another renal tumor that may be difficult to distinguish from CCPC is Xp11.2 translocation RCC. These are typically composed of cells with abundant clear to faintly eosinophilic cytoplasm, arranged in nests and papillary structures. Psammoma bodies are constant and sometimes extensive, often arising within characteristic hyaline nodules. The tumor cells of Xp11 translocation carcinomas characteristically show positive nuclear immunostaining for TFE3, a finding that is not observed in CCPC. Moreover, Xp11.2 translocation RCC does not express CK7 and usually show positive immunostaining for RCC [1-3].

All cases described to date, whether arising in kidneys with end-stage renal disease or in otherwise normal kidneys, have been categorized as pT1 and have exhibited low nuclear grade (Fuhrman grade 1 or 2). Features of biologic aggressiveness, such as extension into perinephric tissue, vascular invasion, or metastasis, have not been observed in these tumors [1-4]. Follow-up data available from patients with CCPC showed no evidence of disease. These observations suggest that this neoplasm may be biologically indolent [1-4]. However, further follow-up studies are needed to better understand its clinical behavior.

Because CCPC exhibit distinctive and clearly definable pathologic characteristic unlike those seen in other renal tumors, they should be regarded as a novel category of renal cell carcinoma.

\section{References}

1. Tickoo SK, dePeralta-Venturina MN, Harik LR, Worcester HD, Salama ME, et al. (2006) Spectrum of epithelial neoplasms in end-stage renal disease: an experience from 66 tumor-bearing kidneys with emphasis on histologic patterns

*Corresponding author: Borislav A Alexiev, MD, Department of Pathology, NBW85, University of Maryland Medical Center, 22 S Greene Street, Baltimore, USA, MD 21201, E-mail: balexiev@umm.edu

Received September 18, 2012; Accepted September 19, 2012; Published September 21, 2012

Citation: Alexiev BA (2012) Clear Cell Papillary Renal Cell Carcinoma: A Nove Category of Renal Cell Neoplasm. J Cytol Histol 3:e107. doi:10.4172/21577099.1000e107

Copyright: (c) 2012 Alexiev BA. This is an open-access article distributed under the terms of the Creative Commons Attribution License, which permits unrestricted use, distribution, and reproduction in any medium, provided the original author and source are credited. 
Citation: Alexiev BA (2012) Clear Cell Papillary Renal Cell Carcinoma: A Novel Category of Renal Cell Neoplasm. J Cytol Histol 3:e107. doi:10.4172/2157-7099.1000e107

Page 2 of 2

distinct from those in sporadic adult renal neoplasia. Am J Surg Pathol 30: 141-153.

2. Gobbo S, Eble JN, Grignon DJ, Martignoni G, MacLennan GT, et al. (2008) Clear cell papillary renal cell carcinoma: a distinct histopathologic and molecular genetic entity. Am J Surg Pathol 32: 1239-1245.

3. Gobbo S, Eble JN, Maclennan GT, Grignon DJ, Shah RB, et al. (2008) Renal cell carcinoma with papillary architecture and clear cell components: the utility of immunohistochemical and cytogenetical analyses in differential diagnosis. Am J Surg Pathol 32: 1780-1786.

4. Bhatnagar R, Alexiev BA (2012) Renal-cell carcinomas in end-stage kidneys: a clinicopathological study with emphasis on clear-cell papillary renal-cel carcinoma and acquired cystic kidney disease-associated carcinoma. Int J Surg Pathol 20: 19-28. 